\title{
Goal-directed therapy in the perioperative management: is a complete hemodynamics bundle of care better?
}

\author{
Nicolas Herzog ${ }^{1^{*}}\left(\mathbb{D}\right.$, Jean-Baptiste Dablin² ${ }^{2}$ Christophe Giacardi ${ }^{1}$ and Marc Danguy des Déserts ${ }^{1}$
}

We read with a deep interest Messina et al.s meta-analysis focusing on goal-directed therapy (GDT) in major visceral/non-cardiac surgery [1]. This research describes a reduction in perioperative complications in favor of GDT therapy, but not an improvement in perioperative mortality. Although the article supports the use of GDT in the perioperative setting, optimal GDT protocol still remains unclear.

The 21 studies included in the analysis can be divided into two subgroups: on the one hand those which only protocolized the fluid management and on the other hand those which protocolized a complete hemodynamics bundle of care including fluid management but also vasopressor or inotrope use. The second subgroup of studies (complete bundle of care) appears to have the most beneficial effect on perioperative complications found in the meta-analysis. This subgroup also included five of the only six studies of the meta-analysis which found a significant effect of GDT on perioperative complications by themselves. Moreover, the two studies with the greatest benefit of GDT also included a mean arterial pressure goal and the use of vasopressors and dobutamine in their protocols [2, 3].

In our opinion, the additional benefit of bundle protocols could be explained by the reduction in hypotension episodes occurrence and duration, thanks to a more frequent screening and a more aggressive treatment of these

*Correspondence: n.herzog@laposte.net; nicolas.herzog@intradef.gouv.fr

${ }^{1}$ Federation of Anesthesiology and Intensive Care Unit, ClermontTonnerre Military Training Hospital, Brest, France

Full list of author information is available at the end of the article episodes in such protocols. In fact, even if the optimal blood pressure target remains controversial, hypotension is a well-known risk factor for complications in the perioperative period [4]. To corroborate this hypothesis, some GDT protocols which included a blood pressure target and interventions to reach it have shown a reduction in hypotension episodes or higher mean arterial pressure levels during the intraoperative period $[2,3]$.

In conclusion, all GDT protocols are not equivalent, and complete hemodynamics GDT protocols seem to be more efficient than fluid management only protocols. We suggest exploring the possible benefit of complete hemodynamics GDT protocols on morbidity and mortality in major visceral and non-cardiac surgery.

\section{Acknowledgements \\ Not applicable.}

\section{Authors' contributions}

$\mathrm{NH}$ and JBD wrote the manuscript, and GC and MDDD revised it. All authors read and approved the final manuscript.

\section{Funding}

Not applicable.

\section{Availability of data and materials}

Data sharing is not applicable to this article as no datasets were generated or analyzed during the current study.

\section{Declarations}

Ethics approval and consent to participate Not applicable.

\section{Consent for publication}

Not applicable. original author(s) and the source, provide a link to the Creative Commons licence, and indicate if changes were made. The images or other third party material in this article are included in the article's Creative Commons licence, unless indicated otherwise in a credit line to the material. If material is not included in the article's Creative Commons licence and your intended use is not permitted by statutory regulation or exceeds the permitted use, you will need to obtain permission directly from the copyright holder. To view a copy of this licence, visit http://creativecommons.org/licenses/by/4.0/. The Creative Commons Public Domain Dedication waiver (http://creativeco mmons.org/publicdomain/zero/1.0/) applies to the data made available in this article, unless otherwise stated in a credit line to the data. 


\section{Competing interests}

The authors declare that they have no competing interests.

\section{Author details}

${ }^{1}$ Federation of Anesthesiology and Intensive Care Unit, Clermont-Tonnerre Military Training Hospital, Brest, France. ${ }^{2}$ Department of Anaesthesiology and Surgical Intensive Care, Centre Hospitalier Et Universitaire de Brest - Université de Bretagne Occidentale, Brest, France.

Received: 23 February 2021 Accepted: 2 March 2021

Published online: 16 March 2021

\section{References}

1. Messina A, Robba C, Calabrò L, Zambelli D, lannuzzi F, Molinari E, et al. Association between perioperative fluid administration and postoperative outcomes: a 20-year systematic review and a meta-analysis of randomized goal-directed trials in major visceral/noncardiac surgery. Crit Care. 2021:25:43.
2. Benes J, Chytra I, Altmann P, Hluchy M, Kasal E, Svitak R, et al. Intraoperative fluid optimization using stroke volume variation in high risk surgical patients: results of prospective randomized study. Crit Care. 2010;14:R118.

3. Mayer J, Boldt J, Mengistu AM, Röhm KD, Suttner S. Goal-directed intraoperative therapy based on autocalibrated arterial pressure waveform analysis reduces hospital stay in high-risk surgical patients: a randomized, controlled trial. Crit Care. 2010;14:R18.

4. Sessler DI, Meyhoff CS, Zimmerman NM, Mao G, Leslie K, Vásquez SM, et al. Period-dependent associations between hypotension during and for four days after noncardiac surgery and a composite of myocardial infarction and death: a substudy of the POISE-2 Trial. Anesthesiology. 2018;128:317-27.

\section{Publisher's Note}

Springer Nature remains neutral with regard to jurisdictional claims in published maps and institutional affiliations.
Ready to submit your research? Choose BMC and benefit from:

- fast, convenient online submission

- thorough peer review by experienced researchers in your field

- rapid publication on acceptance

- support for research data, including large and complex data types

- gold Open Access which fosters wider collaboration and increased citations

- maximum visibility for your research: over 100M website views per year

At BMC, research is always in progress.

Learn more biomedcentral.com/submissions 